\title{
EFEK PEMBERIAN GETAH POHON PISANG BATU (Musa brachycarpa) TERHADAP PERTUMBUHAN Staphylococcus aureus
}

\author{
Sitti Hadijah Syamsuddin \\ Jurusan Analis Kesehatan Poltekkes kemenkes Makassar \\ Email; shitaku2975@gmail.com
}

\begin{abstract}
Abstrak
Penelitian ini dilatar belakangi oleh pemanfaatan getah pohon pisang batu (Musa brachycarpa) yang digunakan sebagai penyembuh luka. Getah pohon pisang efektif untuk memperpendek waktu peradangan. Di samping itu getah pohon pisang dapat berkhasiat sebagai antiseptik. Tujuan penelitian ini untuk mengetahui efek pemberian getah pohon pisang batu terhadap pertumbuhan Staphylococccus aureus. Penelitian ini bersifat deskriktif menggunakan metode difusi agar, di mana digunakan 5 konsentrasi sampel yaitu 10\%, 20\%, 40\%, 60\% dan 80\% pada Staphylococcus aureus. Hasil penelitian ini menunjukkan bahwa terdapat zona hambat pada konsentrasi 20\%, 40\%, 60\% dan 80\%. Di mana bahwa semakin tinggi konsentrasi getah pohon pisang batu maka semakin besar diameter zona hambat yang terbentuk. Dengan demikian, getah pohon pisang batu dapat menghambat pertumbuhan Staphylococccus aureus.
\end{abstract}

Kata Kunci: Staphylococccus aureus, Getah Pohon Pisang Batu

\begin{abstract}
This research is motivated by the utilization of sap of Pisang Batu Tree (Musa brachycarpa) used as wound healer. Banana tree sap effectively shorten the time of inflammation and efficaciously as an antiseptic. The aim of this research is to determine the effect of pisang batu tree sap on Staphylococcus aureus growth. This research is descriptive using agar diffusion method. There are 5 sample concentrations of Banana tree sap, namely 10\%, 20\%, 40\%, 60\%, and $80 \%$ on Staphylococcus aureus. The result of this research shows the inhibitory zone at concentrations of 20\%, 40\%, 60\%, and 80\%. Thus mean that the higher of pisang batu tree sap consentrations the larger diameter of inhibit zone is formed. It is suggested that the sap of pisang batu tree can inhibit the growth of Staphylococccus aureus.
\end{abstract}

Key words: Staphylococcus aureus, Sap of Pisang Batu Tree 


\section{PENDAHULUAN}

Pisang adalah salah satu tanaman buah yang merupakan sumber vitamin, mineral dan karbohidrat. Hampir seluruh tanaman pisang memiliki kandungan nutrisi yang bermanfaat. Baik buah, daun, getah, jantung, bonggol, batang, akar dan kulit pisang memiliki kandungan yang bermanfaat bagi kesehatan maupun kecantikan.

Getah pohon pisang mengandung saponin, asam askorbat, flavonoid dan tanin. Saponin berfungsi sebagai peningkat pembentukan pembuluh darah baru pada luka dan mengencerkan dahak. Selain saponin getah pohon pisang juga mengandung asam askorbat yang berperan memperkuat dam mempercepat pertumbuhan jaringan ikat. Flavonoid yang terkandung dalam getah pisang berperan memperpendek waktu peradangan. Zat tanin pada getah pisang berkhasiat sebagai antiseptik (Susanto, 2016). Pemanfaatan getah pisang digunakan oleh masyarakat sebagai obat tradisional untuk mencegah peradangan dan menyembuhkan luka. Sebelum gel penutup luka dan cairan antiseptik dengan berbagai merek beredar dipasaran, orang-orang zaman dahulu memanfaatkan getah pisang sebagai obat oles pada luka (Hananta, 2006).

Luka yang tidak ditangani dengan benar sering menimbulkan infeksi. Hal ini terjadi karena di kulit banyak flora normal dalam tubuh manusia yang sehat. Mikroorganisme yang umum ditemukan diantaranya Staphylococcus $s p$, Corynebacterium sp, Micrococcus sp, Peptostreptococcus sp dan berbagai Neisseria sp (Natsir, 2008). Staphylococcus aureus merupakan salah satu spesies dari genus Staphylococcus yang dapat menimbulkan penyakit infeksi pada manusia. Staphylococcus aureus dalam jumlah kecil merupakan flora normal pada kulit manusia. Tetapi pada beberapa kasus dapat menyebabkan infeksi jika manusia tersebut mempunyai toleransi yang rendah terhadap mikroorganisme (Natsir, 2013).

Penyakit yang disebabkan oleh bakteri biasanya ditanggulangi dengan pemberian antibiotik. Tetapi, pada saat ini timbul masalah resistensi terhadap beberapa antibiotika yang telah umum digunakan. Beberapa jenis bakteri patogen diantaranya Staphylococcus aureus mempunyai resistensi tertinggi terhadap ampisilin, amoksisilin, penisilin G, tetrasiklin dan kloramfenikol. Kenyataan ini mendorong para ilmuan untuk menyelidiki agen antiinfeksi baru untuk menghasilkan obat-obat baru, misalnya obat yang berasal dari tumbuhan seperti getah pohon pisang.

Keunikan dari kandungan getah pohon pisang ini diketahui dari hasil penelitian yang dilakukan oleh Priosoeryanto (2006) pada getah batang pisang. Menurut penelitian dari Laboratorium Patologi Veteriner, Bagian Parasitologi dan Patologi, Fakultas Kedokteran Hewan Institut Pertanian Bogor bahwa luka pada mencit yang diolesi getah pelepah pisang menutup dua kali lebih cepat daripada luka pada mencit yang tidak diobati dan tidak meninggalkan jaringan parut. Pengamatan secara mikroskopik memperlihatkan bahwa pemberian ektrak getah pohon pisang mempercepat keringnya luka, terlepas keropeng dan fibroris sehingga secara umum pemberian sediaan ekstrak getah pelepah pisang memberikan hasil yang lebih baik. Kemampuan getah pelepah pisang menyembuhkan luka diduga akibat kandungan saponin, antrakuinon dan kuinon 
yang berfungsi sebagai antibiotik dan analgetik. Sementara kandungan lektin berfungsi menstimulasi pertumbuhan sel kulit (Hananta, 2006).

Dari uraian di atas yang menjelaskan bahwa kandungan getah pohon pisang memiliki efek antibiotik terhadap Staphylococcus Aureus yang merupakan salah satu penyebab infeksi. Oleh karena itu, perlu dilakukan penelitian ilmiah tentang efek pemberian getah pohon pisang batu terhadap pertumbuhan Staphylococcus aureus sebagai alternatif untuk pengobatan terhadap infeksi oleh Staphylococcus aureus mengingat sifat bakteri tersebut yang multiresisten terhadap banyak antibiotik.

\section{METODOLOGI PENELITIAN}

Jenis penelitian ini adalah deskriktif, dimaksudkan untuk menentukan kemampuan getah pohon pisang dalam menghambat pertumbuhan bakteri Staphylococcus aureus. Penelitian ini dilaksanakan di laboratorium Bakteriologi Kampus Jurusan Analis Kesehatan Poltekkes Kemenkes Makassar. Sampel penelitian ini adalah getah pohon pisang batu dengan konsentrasi sampel 10\%, 20\%, 40\%, 60\% dan $80 \%$.

Adapun prosedur kerja dalam penelitian ini adalah melakulkan sterilisasi dimana alat yang digunakan terlebih dulu dicuci dengan deterjen dan dibilas dengan air suling, untuk alat-alat yang tahan pemanasan tinggi disterilkan dengan menggunakan oven pada suhu $180^{\circ} \mathrm{C}$ selama 2 jam. Sedangkan alat-alat dan bahan yang tidak tahan pemanasan tinggi disterilkan dengan menggunakan autoklaf pada tekanan $1 \mathrm{~atm}$ dengan suhu $121^{\circ} \mathrm{C}$ selama 15 menit. Alat logam disterilkan dengan cara dipijarkan dengan meggunakan lampu spiritus. Melakukan pembuatan $\mathrm{NaCl} 0,9 \%$ dengan menimbang bahan $\mathrm{NaCl}$ sesuai dengan volume media yang yang akan dibuat. Bahan yang telah ditimbang dilarutkan dengan akuades di dalam bekerglass. Selanjutnya dimasukkan kedalam labu ukur (sesuai dengan volume yang ingin dibuat). Lalu cukupkan dengan akuades hingga garis batas. Kemudian dimasukkan ke dalam tabung masing-masing $5 \mathrm{ml}$, lalu disterilkan dalam autoclave pada suhu $121^{\circ} \mathrm{C}$ selama 15 menit.

Setelah disterilkan, siap untuk dipakai. Pembuatan media MHA dilakukan dengan membuat komposisi media MHA yaitu pepton (6 g), kasein (17,5 g), pati (1,5 g) dan agar $(10 \mathrm{~g})$. Semua kandungan tersebut (38 g ) dilarutkan dalam 1 liter (1000 ml) akuades. Cara membuatnya: 38,0 g bahan ditimbang, dilarutkan dalam akuades sampai volume $1000 \mathrm{ml}$, diatur pH-nya. Disterilkan dalam autoklaf $121^{\circ} \mathrm{C}$ selama 15 menit. Dibiarkan dingin sampai mencapai suhu $45-50^{\circ} \mathrm{C}$ (dapat pula disimpan di lemari es). Adapun pembuatan media NA dilakukan dengan komposisi media NA adalah Beef Extract 3,0 g, Pepton 5,0 g dan Agar $15 \mathrm{~g}$. Semua kandungan tersebut dilarutkan dalam 1 liter (1000 ml) akuades. Cara membuatnya: Sebanyak 23,0 g medium disuspensikan ke dalam satu liter aquades atau deionized. Medium dipanaskan sampai mendidih agar tercampur dengan sempurna selama 1 menit. Disterilisasi dalam autoklaf selama 15 menit, pada suhu $121^{\circ} \mathrm{C}$, tekanan 1-2 atm. Tunggu hingga agak dingin sekitar suhu 40$45^{\circ} \mathrm{C}$. Taruh ke cawan petri atau tabung reaksi untuk membuat agar miring. Bakteri uji 
yang digunakan diperoleh dari Balai Laboratorium Kesehatan Makassar seksi mikrobiologi, stok biakan murni bakteri tersebut diambil dengan menggunakan nald kemudian dimasukkan ke dalam tabung reaksi lalu diinokulasi secara zig-zag pada media Nutrient Agar kemudian diinkubasi ke dalam inkubator pada suhu $37^{\circ} \mathrm{C}$ selama 1 $\times 24$ jam. Bakteri uji siap digunakan.

Pembuatan standar kekeruhan Mc.Farland dilakukan dengan membuat larutan 0,6 ml Barium klorida $\left(\mathrm{BaCl}_{2}\right)$ 1\% dituang kedalam gelas ukur $100 \mathrm{ml}$. dan dipenuhi dengan $\mathrm{H}_{2} \mathrm{SO}_{4} 1 \%$ sampai mencapai $100 \mathrm{ml}$. Tutup rapat agar tidak terjadi penguapan. Pembuatan Suspensi Bakteri dilakukan dengan mengambil biakan menggunakan ose pada satu koloni bakteri uji yang telah disiapkan atau diremajakan, disuspensikan dengan $\mathrm{NaCl}$ 0,9\%, kemudian diukur tingkat kekeruhannya dengan menggunakan standar kekeruhan Mc. Farland. Pada persiapan sampel, dilakukan penampungan getah pohon pisang batu yang diambil langsung dari pohonnya ke dalam wadah. Pembuatan konsentrasi getah pohon pisang batu dilakukan dengan cara mengencerkan getah pohon pisang batu. Pengenceran dibuat 10\%, 20\%, 40\%, 60\% dan 80\%. Data yang diperoleh analisis deskriktif yang ditampilkan dalam bentuk tabel dan gambar kemudian dibahas secara narasi.

\section{HASIL PENELITIAN DAN PEMBAHASAN}

Dari hasil penelitian yang dilakukan dengan menggunakan uji daya hambat getah pohon pisang batu terhadap pertumbuhan Staphylococcus aureus yang dilakukan di laboratorium Bakteriologi Kampus Jurusan Analis Kesehatan Poltekkes Kemenkes Makassar pada bulan Juni diperoleh hasil sebagai berikut :

Tabel 1. Hasil Pengukuran Zona Hambat Terhadap Pertumbuhan

Bakteri Staphylococcus aureus

\begin{tabular}{lll}
\hline No & Konsentrasi & $\begin{array}{l}\text { Diameter Zona Hambat } \\
(\mathbf{m m})\end{array}$ \\
\hline 1 & $10 \%$ & 0 \\
2 & $20 \%$ & 7,5 \\
3 & $40 \%$ & 10,5 \\
4 & $60 \%$ & 18,5 \\
5 & $80 \%$ & 50 \\
6 & Kontrol (-): Akuades & 0 \\
7 & $\begin{array}{l}\text { Kontrol } \quad(+) \\
\text { Kloramfenikol }\end{array}$ & 23,5 \\
\hline
\end{tabular}

Sumber : Data primer 2017 
Dari tabel 1. Diatas menunjukkan terbentuk zona hambat setelah inkubasi 24 jam pada suhu $37^{\circ} \mathrm{C}$. hal tersebut menunjukkan bahwa getah pohon pisang batu mempunyai efek dalam menghambat pertumbuhan Staphylococcus aureus. Diameter yang terbentuk berdasarkan konsentrasi getah pisang batu yang digunakan adalah sebesar 7,5 mm pada konsentrasi 20\%, 10,5 mm pada konsentrasi 40\%, 18,5 mm pada konsentrasi $60 \%$ dan $50 \mathrm{~mm}$ pada konsentrasi $80 \%$. Pada konsentrasi $10 \%$ dan kontrol negatif (akuades) tidak terbentuk zona hambat sedangkan pada kontrol positif (Kloramfenikol) membentuk zona hambat dengan diameter sebesar 23,5 mm.

\section{PEMBAHASAN}

Dari hasil uji daya hambat getah pohon pisang batu terhadap pertumbuhan Staphylococcus aureus memperlihatkan zona hambat yang terbentuk pada konsentrasi $20 \%, 40 \%, 60 \%$ dan $80 \%$. Untuk masing-masing konsentrasi menunjukkan bahwa zona hambat terbesar terbentuk pada konsentrasi $80 \%$, yaitu sebesar $50 \mathrm{~mm}$. Pada konsentrasi $60 \%$ zona hambat yang terbentuk sebesar $18,5 \mathrm{~mm}$. Pada konsentrasi $40 \%$ zona hambat yang terbentuk sebesar $10,5 \mathrm{~mm}$. Pada konsentrasi $20 \%$ zona hambat yang terbentuk sebesar 7,5 mm. Pada konsentrasi $10 \%$ tidak terbentuk zona hambat. Pada kontrol negatif (akuades) tidak terbentuk zona hambat sedangkan pada kontrol positif terbentuk zona hambat dengan diameter sebesar $23,5 \mathrm{~mm}$.

Pada getah pohon pisang batu dengan konsentrasi $80 \%$ terbentuk zona hambat sebesar $50 \mathrm{~mm}$ yang melebihi besar diameter zona hambat kontrol positif (Kloramfenikol) yaitu sebesar $23,5 \mathrm{~mm}$, sehingga getah pohon pisang dengan konsentrasi $80 \%$ lebih efisien menghambat pertumbuhan Staphylococcus aureus daripada Kloramfenikol. Dari hasil uji menunjukkan bahwa pada setiap konsentrasi memiliki diameter zona hambat yang terbentuk berbeda-beda. Peningkatan konsentrasi getah pohon pisang batu sebanding dengan diameter zona hambat yang terbentuk. Semakin tinggi konsentrasi dari getah pohon pisang batu maka diameter zona hambat yang terbentuk semakin besar pula. Hal ini menandakan bahwa aktifitas antimikroba getah pohon pisang batu meningkat seiring dengan peningkatan konsentrasi. Hasil penelitian Hepni, 2017 tentang analisis buah pisang batu menyatakan bahwa, fraksi buah pisang batu yang memberikan aktivitas antibakteri yang paling kuat terhadap bakteri uji adalah fraksi etilasetat, sedangkan fraksi n-heksan tetap memberikan aktivitas tetapi dalam konsentrasi yang sedikit. Selain itu, mekanisme kerja penghambatan bakteri uji terhadap fraksi buah pisang batu melalui perusakan membran sel dapat dilakukan hanya terhadap fraksi etilasetat. Hasil mekanisme kerjanya yaitu kebocoran metabolit seluler memperlihatkan bahwa kebocoran sel terjadi lebih banyak pada senyawa protein dibandingkan dengan asam nukleat, sedangkan hasil kebocoran ion-ion logam memperlihatkan bahwa kebocoran sel terjadi lebih banyak pada ion $\mathrm{K}+$ dibandingkan dengan ion $\mathrm{Ca}+$, dan hasil analisis morfologi sel bakteri memperlihatakan bahwa kerusakan sel terjadi pada membran sel. 
Hasil analisa diameter zona hambat pertumbuhan Staphylococcus aureus menunjukkan bahwa getah pohon pisang memiliki efek antimikroba terhadap $S$. aureus. Efek antimikroba getah pohon pisang terhadap S.aureus disebabkan kandungan aktifnya yaitu saponin, kuinon dan antrakuinon yang terdapat dalam getah pohon pisang yang menyebabkan rusaknya membran sitoplasma Staphylococcus aureus sehingga menyebabkan gangguan metabolisme energi dan pertumbuhan bakteri tersebut. Pada penelitian Ngajow, dkk., 20013 dan Akiyama 2001dinyatakan bahwa mekanisme kerja saponin pada getah kulit buah pisang goroho sebagai antibakteri yaitu menurunkan tegangan permukaan sel bakteri yang berakibat naiknya permeabilitas atau kebocoran sel sehingga senyawa intrasel akan keluar. Saponin juga berperan dengan mengganggu stabilitas membran sel bakteri sehingga menyebabkan sel bakteri lisis. Mekanisme kerja tannin sebagai antibakteri yaitu berhubungan dengan kemampuannya untuk menginaktifkan adhesi sel mikroba dan enzim, serta menggangu transport protein pada lapisan dalam sel.

\section{KESIMPULAN}

Dari penelitian yang dilakukan di laboratorium Bakteriologi Kampus Jurusan Analis Kesehatan Poltekkes Kemenkes Makassar dapat disimpulkan bahwa terdapat efek pemberian getah pohon pisang batu terhadap pertumbuhan Staphylococcus aureus, yaitu pada konsentrasi $80 \%$ terbentuk zona hambat sebesar $50 \mathrm{~mm}$, konsentrasi $60 \%$ terbentuk zona hambat $18,5 \mathrm{~mm}$, konsentrasi $40 \%$ terbentuk zona hambat $10,5 \mathrm{~mm}$, konsentrasi $20 \%$ terbentuk zona hambat $7,5 \mathrm{~mm}$ dan konsentrasi $10 \%$ tidak berbentuk zona hambat.

\section{DAFTAR PUSTAKA}

Akiyama H, Fujii K, Yamasaki O, Oono T, Iwatsuki K. (2001). Antibacterial Action of Several Tannins Against Staphylococcus Aureus. J Antimicrob Chemother.;48(4):487-91

Dalimartha, S. (2007). Atlas Tumbuhan Obat Indonesia. Puspa Sehat. Jakarta.

Dicky, A. 2016. Perbandingan Efek Pemberian Ektrak Temulawak (Curcuma xanthorrhiza Roxb) Terhadap Daya Hambat Pertumbuhan

Staphylococcus aureus dan Escherichia coli Secara In Vitro. Fakultas Kedokteran Universitas Lampung. (online): (http://digilib.unila.ac.id). Diakses pada 14 april 2017.

Hananta, D. (2006). Efek Getah Pelepah Pisang (Musa spp) Terhadap Pertumbuhan Pseudomonas aeruginosa Secara In Vitro. Universitas Muhammadiyah Malang. (online): (http://studentresearch.umm.ac.id) Diakses 14 April 2017. 
Hepni. (2017). Analisis Fraksi Buah Pisang Batu (Musa balbisianae Colla) yang Bersifat Sebagai Antibakteri dan Mekanismenya, Universitas Sumatera Utara . (Online) : (http://repositori.usu.ac.id) Diakses 30 Juni 2018

Hernan, R. (2006). MRSA and Staphylococcal Infections. United States of America. America.

Kusuma , S.A.F. (2009). Staphylococcus aureus. Universitas Padjadjaran Fakultas Farmasi. (online): (http://repository.unpad.ac.id) Diakses 10 Mei 2017.

Ngajow M, Abidjulu J, Kamu VS. Pengaruh Antibakteri Ekstrak Kulit Batang Matoa (Pometia Pinnata) terhadap Bakteri Staphylococcus Aureus. Jurnal MIPA Unsrat. 2013;2:(2):131.

Natsir.M, dan Sartini. (2008). Analis Mikrobiologi Farmasi. Makassar: Laboratorium Mikrobiolgi Farmasi Fakultas Farmasi Universitas Hasanuddin Makassar.

Natsir.M, dan Sartini. (2013). Dasar-Dasar Mikrobiologi Farmasi. Laboratorium Mikrobiolgi Farmasi Fakultas Farmasi Universitas Hasanuddin Makassar. Makassar.

Nazaruddin \& Fauziah M. (2006). Buah Komersial. Penebar Swadaya. Jakarta.

Priosoeyanto, B.P. (2006). Aktifitas Getah Batang Pisang Dalam Proses Penyembuhan Luka dan Efek Kosmetiknya pada Hewan. Institut Pertanian Bogor. Bogor. (online): (http://repository.ipb.ac.id) Diakses pada 13 April 2017.

Rosenthal. (2011). International Nasokomial Infection Control Consortium(INCC) Report Data Summary of 36 Countries for 2004-2009. INCC Report 20042009. Vol $366: 627-37$.

Setiawati, A. (2015). Peningkatan Resistensi Kultur Bakteri Staphylococcus aureus terhadap Amoxilin menggunakan Metode Adaptif Gradual. Universitas Sanata Dharma Yogyakarta. Yogyakarta. (online): (https://www.usd.ac.id) Diakses 14 April 2017.

Susanti \& Ahmad S. (2008). Pisang, Budidaya, Pengolahan dan Prospek Pasar. Penebar Swadaya. Jakarta.

Susanto, T. (2016). Untung Berlipat dari Berkebun Pisang. Air Publishing. Jawa Barat.

Wasitaningrum, I.D.A. (2009). Uji Resistensi Bakteri Staphylococcus aureus dan Escherichia coli dari isolate susu sapu segar terhadap beberapa antibioti. (online): (http://eprints.ums.ac.id). Diakses pada 13 April 2017. 